\title{
The Medicolegal Certification of Medical Fitness for Work:
}

\section{Necessity of Standardization of the Certificate}

\author{
Milan Tuček ${ }^{1}$ \\ ${ }^{1}$ Institute of Hygiene and Epidemiology, First Faculty of Medicine, Charles University, Prague, Czech Republic
}

\begin{abstract}
Background: One of the crucial medicolegal activity of occupational medical service (OMS) providers is the certification of medical fitness for work issued by examining physician and based on knowledge of working conditions/health risks at work and on results of occupational medical examinations.

Objective: Recommended standards for the content and scope of preventive medical examinations in the listed exposures and loads are available. The employers need clear and standardized final decision about the medical fitness for work without sensitive medical data (diagnosis) issued by examining physician.

Material and Methods: The author analyzed the content of 18125 certificates of medical fitness for work in the period $1982-2012$ and compared different written forms of certification based on actual legislation.
\end{abstract}

Results: In the 30 years period there were used different written forms of certification of medical fitness for work. From this long experience resulted necessary content of certificate of medical fitness assessment for work which was standardized in the new law (Czech Republic Act No 373/2011 Dig., on specific health services and Decree of The Ministry of Health No.79/2013 Dig., on occupational medical services).

Conclusion: Although the content of certificate of medical fitness assessment for work was standardized, different written or electronic forms of certification of medical fitness for work should be unified and standardized for practical needs of OMS providers and employers.

\section{Keywords}

occupational health/medical services - medical fitness certification - standardization of the certificate

\section{Correspondence to:}

\section{Milan Tuček}

Institute of Hygiene and Epidemiology,

First Faculty of Medicine, Charles University

Address: Studničkova 7, 12800 Praha 2 (Prague)

E-mail: milan.tucek@If1.cuni.cz

\section{EJBI 2013; 9(1):7-10}

recieved: August 5th, 2013

accepted: September 26th, 2013

published: October 14th, 2013

\section{Introduction}

The Czech Republic Act No 373/2011 Dig., on specific health services (valid since April 1, 2012) [2] defines in paragraphs 53 - 60 Occupational Medical Services (OMSs) as preventive services, which include the impact assessment of work, working environment and working conditions on health, workplace inspections and preventive medical fitness assessment for work aimed at protecting the health and protection against occupational accidents, occupational diseases and work-related diseases, training in first aid and regular surveillance in the workplace.

Providers of occupational medical services are general practitioners (GP's) or occupational health specialists (certified/recognized occupational physicians) [6]. The employee is obliged to undergo all preventive medical occupational examinations indicated by OMS provider for the evaluation of health status. The employer is obliged to assign of employees to work in compliance with the conclusions of the medical report/certificate about their medical fitness.

\section{Methods and Materials}

\subsection{Competence of OMS Providers}

The provider of occupational medical services is required [1, 3, 8]:

- to inform employee about the possible influence of factors of working conditions on his/her health, and with knowledge of the development of his/her state of health, 


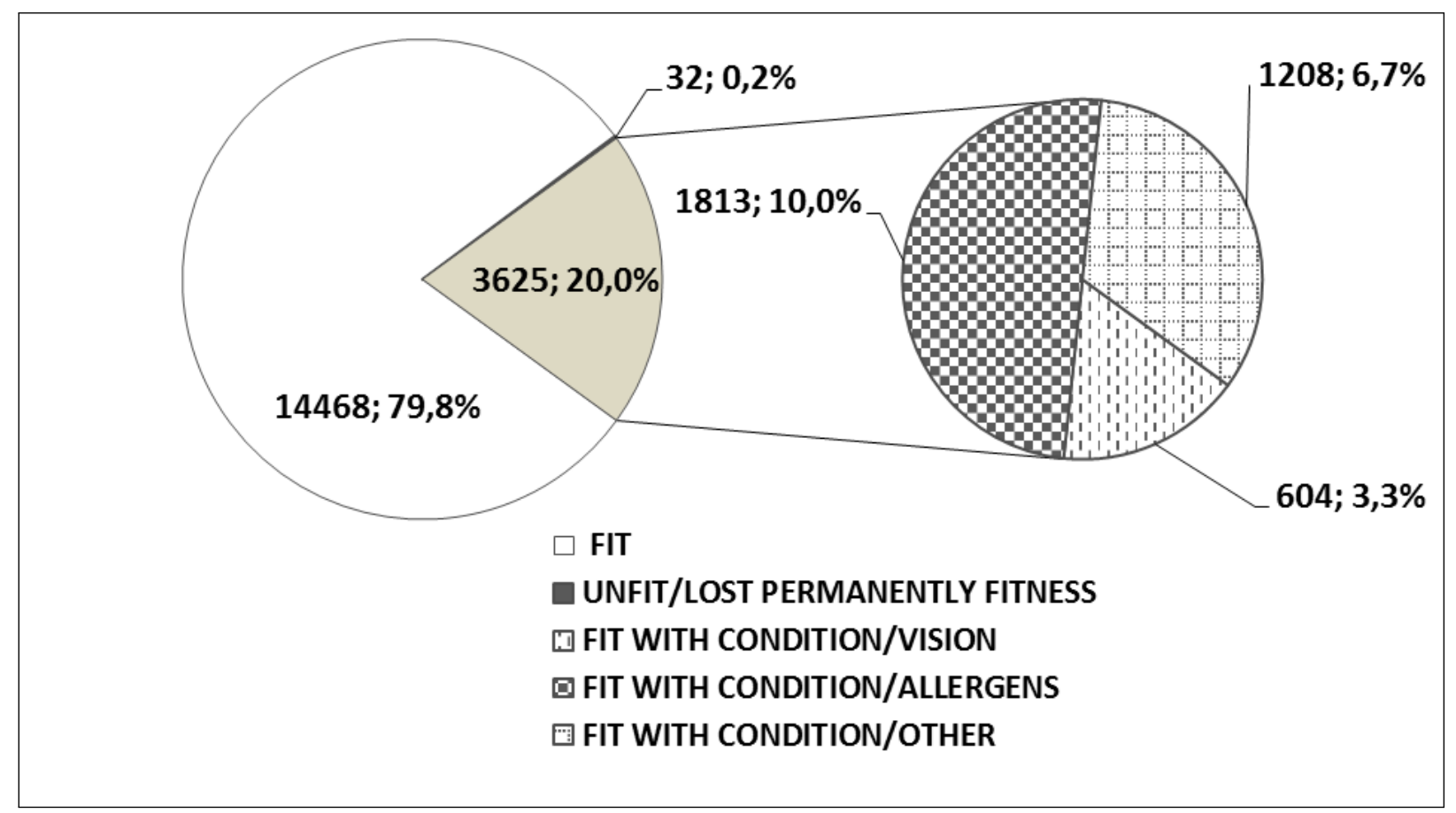

Figure 1: Medical fitness assessment 1982 - 2012 (18 125 certificates).

- to inform employers about the possible influence of factors of working conditions on the health of employees,

- to perform periodic monitoring of the workplace conditions,

- to cooperate with the employer, employee, safety and health at work specialist, governmental inspection authorities and trade unions,

- to notify promptly the employer of serious or repeated facts adversely affecting health and safety at work

- through employer to ensure the measurement/expertise and analysis of the working conditions, working environment including the results of categorization of health risks

Standardized certificate of medical fitness assessment for work must include

- identification of the employer's,

- identification of medical provider and physician/signature, Nr. of certificate,

- identification of the persons employed or seeking employment: the name or names and surname, date of birth, address of permanent residence in the Czech Republic or the address of the registered place of temporary residence,

- details of the job position or employee data of the expected job title of person applying for employment, further information on the nature of work,
- mode of operation, the risk factors in relation to specific work, the degree of working risk factors, job categories expressed by the key risk factors of working conditions,

- the term an extraordinary examination, if such a procedure is justified,

- date of issue of certificate,

- information about the possibility of appeal procedure,

- final assessment (4 possibilities):

- is medically fit,

- is medically fit with the certain condition/medical restriction,

- is medically unfit,

- lost permanently medical fitness.

\subsection{Principles of Medical Fitness Assessment for Work and Analyzed Data}

One of the crucial medicolegal activity of OMS providers is the certification of medical fitness for work issued by examining physician and based on knowledge of working conditions, knowledge of health risks of work and on results of occupational medical examinations [4].

A keystone of quality performance by an occupational physician is the familiarity with specific working conditions and demands of the respective job and the knowledge of the state of health of individual workers. Occupational 
medical examinations of individuals (workers and employees) are initial/entry, periodic, extraordinary, output and consequential [5].

System of categorization of work operations established in the Czech Republic is based on monitoring 13 harmful factors in the workplace (dust, chemical substances, noise, vibrations, electromagnetic fields, physical load, working position, thermal exposure, cold exposure, psychical burden, visual burden, biological agents, high air pressure). Special guidelines for assessment of various types of risks are available.

The category of the work operation and the most important risk factor determine the frequency and range of periodic medical examination of workers and frequency of periodic measurements of different harmful factors at workplaces.

Some occupations (drivers, railway workers, firemen etc.) have besides the examinations above special content of preventive medical examinations [7].

Working population in the Czech Republic currently totals about 4.5 million people working in 74731 subjects/enterprises (in 2011). Because there is not central register of certificates of medical fitness for work, author based this analysis on his own data (18125 certificates) since 1982 till 2012 (at about 600 certificates per year). The whole database was not in the electronic form so it was necessary to compare forms and final assessment data from paper health records (Fig. 1).

\section{Results and Discussion}

Problem of medical fitness assessment for work is not only in the content and scope of preventive medical examination (their effectiveness), but in the amount and form of the legal aspects of certificate of medical fitness assessment for work too, what is utterly incomparable with the simplified situation decades ago (the latest legislation originated in 2013 after 46 years). The list of obligatory requirements of the employer's request and certificate of medical fitness for work is unnecessarily large and ambiguous in details (see part 2.1.

The terms used in law are often very far from an expert terminology (e.g. hazard versus risk). There is only exceptionally available standard form in law (standardized certificate form for medical fitness assessment for road drivers), so the practice is diverse, confusing and legally problematic. The result is a series of cancellations of medical fitness certificates for work in appeal procedures for formal defects. There is another problem: the combination of two approaches to the medical fitness assessment for work - evaluation of working risk factors on one side (e.g. noise, dust) and claims of the job on the other side (eg firemen, vehicle drivers).

There exists an integrated approach called "occupational health characteristics" - maybe less precise, but perhaps more useful for practice. Indeed, many aspects of the medical fitness assessment for work undergo certain rationalization in medical practice.

The content of preventive medical examinations depended on grade of risk of different occupations of examined persons and was not the aim of analysis. The data analysis was focused on the form of the certificate (the form was influenced by unpredictable current requirements and changes in legislation during the analyzed period for different occupations, f.i. drivers) and its conclusions (medically fit, medically fit with the certain condition/medical restriction, medically unfit/lost permanently medical fitness). The main limitation of medical fitness to work was represented by allergic diseases in history and impaired vision. Other limitations (for shift work, work at heights etc.) occurred less frequently (Fig. 1).

\section{Conclusions}

The certificate of medical fitness for work does not contain sensitive medical data (diagnosis). On the other side there must be clearly expressed that the assessed person is medically fit for the job or medically fit for the job with the certain condition/medical restriction or medically unfit (sometimes permanently) for the job [6]. There are different written or electronic forms for certification of medical fitness for work that should be unified and standardized for practical needs of OMS providers and employers. The introduction of the standard of employer's request and certificate of medical fitness for work would be useful for the current practice, the correct use of this standard would largely eliminate risk of the annulment of certificate from formal mistakes in appeal procedure. Conceptual unification and cohesion of existing legislation is an obvious prerequisite for the success of standardization [9].

\section{Acknowledgements}

Supported by scientific programme PRVOUK P25/LF1/2 of Charles University in Prague, Czech Republic.

\section{References}

[1] Cikrt M, Pelclová D, Markvart K, Lukáš E, Kříž J. Occupational and environmental medicine in Czech Republic. Int Arch Occup Environ Health 69 (1997), 79-82.

[2] Czech Republic Act No 373/2011 Dig., on specific health services (in Czech)

[3] Leino, T.,Räsänen, K., Kauppinen, T., Liira, j., Jakkola, J., Carnevale,F., Baldasseroni, A., Van Damme, K., Casteleyn, L., Veidebaum,T., Kahn, H., Vilkis, A., Eglite, M., Jekabsone, I., Vanadzins, I., Jankauskas, R., Černá, M., Tuček, M., Málek, B., Cikrt, M., Pelclová, D., Šmerhovský, Z. Comparative analysis of occupational health system and practices as part of preventive health care systems in seven European countries. Part 1 Document based analysis. EU INCO - Copernicus project No. PL 973108, 1999.

[4] Tuček, M., Pelclová, D., Cikrt, M.. Pracovní lékařství pro praxi .(Occupational Medicine for Practice). Příručka s do- 
poručenými standardy. (Handbook with Recommended Standards). Grada Publishing, Prague (in Czech), 2005.

[5] Tuček, M. Analýza pracovně lékařské péče v České republice. (Analysis of occupational medical care in the Czech Republic), Ceské pracov. lék. (in Czech, English abstract), 6 (2005), $28-36$.

[6] Tuček ,M.: Pracovnělékařské služby jako součást zdravotnické reformy. Zdravotnické fórum (2012), 18-20.
[7] Tuček, M. Transport safety, neurobehavioral disorders and medical fitness standards. Neural Network World, 6 (2010), 723736 .

[8] Westerholm, P., Baranski, B. (eds) . WHO Guidelines on Quality Management in Multidisciplinary Occupational Health Services. WHO European Center for Environment and Health, Bilthoven 1999.

[9] Šubrt, B., Tuček, M: Pracovnělékařské služby (Occupational medical services). ANAG Publishing, Olomouc (in Czech), 2013 